\title{
Ketahanan Padi Transgenik $D B 1$ terhadap Penggerek Batang Padi Kuning Scirpophaga incertulas Walker (Lepidoptera: Pyralidae)
}

\author{
Nono Carsono ${ }^{1 *}$, Irma Mangatur ${ }^{2}$, Fitri Utami Hasan ${ }^{3}$, Santika Sari ${ }^{1}$, Nenet Susniahti ${ }^{4}$, Hersanti $^{4}$ \\ dan Baehaki S.E. ${ }^{5}$ \\ ${ }^{1}$ Departemen Budidaya, Fakultas Pertanian, Universitas Padjadjaran, Kampus Jatinangor 45363 \\ ${ }^{2}$ Alumni Program Studi Agroteknologi, Fakultas Pertanian, Universitas Padjadjaran \\ ${ }^{3}$ Mahasiswa Program Studi Magister Agronomi, Fakultas Pertanian, Universitas Padjadjaran \\ ${ }^{4}$ Departemen Hama dan Penyakit Tumbuhan, Fakultas Pertanian, Universitas Padjadjaran \\ ${ }^{5}$ Balai Besar Penelitian Tanaman Padi, Sukamandi-Subang \\ *Alamat korespondensi: n.carsono@unpad.ac.id
}

\begin{abstract}
Resistance of $D B 1$ transgenic rice to the yellow rice stem borer (Scirpophaga incertulas Walker) (Lepidoptera: Pyralidae)
\end{abstract}

Decrease in rice production in Indonesia can be fulfilled by improving quality and quantity of rice. Rice stem borer (Scirpophaga incertulas) is an important pest that considered being detrimental to rice. The aim of this study was to determine resistance level of $D B 1$ transgenic rice which compared to cv. Taichung-65 (wild-type), Ciherang and IR64 to the pest. Experiments were arranged in Completely Randomized Design and Randomized Block Design. The result showed that $D B 1$ transgenic rice, Taichung-65, IR64 and Ciherang were susceptible with scale 9. The mortality of $D B 1$ transgenic rice was not significantly different with Taichung-65, IR64 and Ciherang. The low levels of resistance in $D B 1$ transgenic rice, Taichung-65, IR64 and Ciherang were also seen in development and growth time of $S$. incertulas. There was no disruption on development and growth of $S$. incertulas. $D B 1$ genes were still not enough to provide maximum resistance to $S$. incertulas and still need to discover information of other genes that can be inserted and increase the resistance of rice to $S$. incertulas.

Keywords: Transgenic rice, $D B 1$ transgene, Yellow rice stem borer

\begin{abstract}
ABSTRAK
Serangan hama telah menurunkan produksi beras, salah satu hama utama di Indonesia adalah penggerek batang padi kuning (Scirpophaga incertulas). Penelitian ini bertujuan untuk mengetahui tingkat ketahanan padi transgenik $D B 1$ dibanding dengan padi Taichung-65 (padi originnya), Ciherang dan IR64 terhadap penggerek ini. Pada penelitian ini dilakukan pengujian tingkat ketahanan terhadap $S$. incertulas pada padi yang diuji. Percobaan ditata dengan Rancangan Acak Lengkap dan Rancangan Acak Kelompok. Hasil penelitian menunjukkan bahwa padi transgenik $D B 1$, Taichung-65, IR64 dan Ciherang tergolong padi berketahanan rentan dengan skala 9. Mortalitas padi transgenik $D B 1$ tidak berbeda nyata dengan padi Taichung-65, IR64 dan Ciherang. Rendahnya tingkat ketahanan pada padi transgenik $D B 1$, Taichung-65, IR64 dan Ciherang juga terlihat pada lama perkembangan dan pertumbuhan $S$. incertulas yang relatif sama, tidak tampak gangguan perkembangan dan pertumbuhan $S$. incertulas. Gen $D B 1$ masih belum cukup untuk memberikan ketahanan maksimal terhadap $S$. incertulas. Perlu dicari sumber gen lain guna meningkatkan ketahanan tanaman padi terhadap $S$. incertulas.
\end{abstract}

Kata Kunci: Padi transgenik, Gen $D B 1$, Penggerek batang padi kuning 


\section{PENDAHULUAN}

Padi (Oryza sativa L.) merupakan komoditi pangan yang mendapat prioritas utama dalam pembangunan pertanian. Seiring dengan peningkatan jumlah penduduk, maka kebutuhan akan beras di negara kita juga terus meningkat dan untuk mengatasi kebutuhan beras yang terus meningkat maka diperlukan upaya keras dalam peningkatan produksi beras baik kualitas maupun kuantitas. Dalam upaya peningkatan produksi beras, sering ditemui beberapa hambatan. Salah satu hambatan yang selalu mengancam produksi beras adalah serangan hama dan patogen. Hama penting tanaman padi yang dianggap merugikan baik di Indonesia maupun di negara-negara Asia lainnya adalah penggerek batang padi (Soehardjan, 1976). Penggerek batang padi kuning (Scirpophaga incertulas) dapat menyerang tanaman padi pada semua stadium pertumbuhan. Pada stadium vegetatif, serangan hama mengakibatkan kematian anakan muda dan gejalanya disebut sundep. Pada stadium generatif, serangan hama menyebabkan malai tampak putih dan gabah menjadi hampa yang disebut beluk (Bandong \& Litsinger, 2005).

Sampai saat ini belum ada varietas padi dengan tingkat ketahanan yang memadai terhadap penggerek batang padi (Bandong \& Litsinger, 2005). Hal ini disebabkan sumber gen ketahanan terhadap penggerek batang padi belum ditemukan pada tanaman padi budidaya maupun padi liar (Rao \& Padhi, 1988). Upaya pengendalian yang dapat dilakukan dalam mengurangi kerugian yang disebabkan oleh serangan hama padi adalah merakit tanaman yang tahan. Perakitan tanaman padi transgenik tahan hama merupakan teknologi alternatif yang dapat dipakai dalam pengendalian hama (Bahagiawati \& Rijzaani, 2005). Penggunaan tanaman padi tahan memiliki pengaruh yang sangat besar dalam penekanan serangan $S$. incertulas. Tanaman padi tahan yang digunakan dapat berupa padi transgenik yang disisipi oleh gen tahan terhadap $S$. incertulas.

Salah satu gen tahan terhadap serangga adalah gen $D B 1$ (Dioscorea batatas) yang menghasilkan lektin dan mempunyai kemampuan insektisidal sehingga menimbulkan efek toksik terhadap serangga jika terbawa sampai saluran pencernaan (Gaidamashvili et al., 2004). Gen $D B 1$ ini dapat diisolasi dari Dioscorea batatas dan telah terbukti menghambat perkembangan Helicoverpa armigera Hübner (Gaidamashvili et al., 2009;
Ohizumi et al., 2009). Gen $D B 1$ ini telah disisipkan ke dalam padi Taichung 65 (padi tipe japonica) asal Taiwan dengan menggunakan metode transformasi yang dimediasi Agrobacterium (Toriyama, 2010). Genotipe padi transgenik $D B 1$ diharapkan tahan terhadap penggerek batang padi kuning khususnya yang ada di Indonesia. Oleh karena itu, pada penelitian ini dilakukan pengujian tingkat ketahanan terhadap $S$. incertulas pada padi transgenik $D B 1$ serta tanaman padi nontransgenik yaitu padi Taichung-65, dan IR64, dan Ciherang.

\section{BAHAN DAN METODE}

Materi genetik yang digunakan dalam penelitian ini adalah padi transgenik $D B 1$, Taichung-65, IR64, dan Ciherang. Penelitian ditata dalam rancangan percobaan Rancangan Acak Lengkap (RAL) dan Rancangan Acak Kelompok (RAK). RAL menguji mortalitas penggerek batang padi kuning ( $S$. incertulas) dilakukan 4 perlakuan yang diulang 20 kali. Pengaruh padi transgenik terhadap lama perkembangan dan pertumbuhan penggerek batang padi kuning ( $S$. incertulas) dilakukan 4 perlakuan dan diulang 20 kali. Percobaan ditata dalam RAK terdiri dari uji ketahanan padi transgenik terhadap penggerek batang padi kuning secara in planta (tanaman hidup) dilakukan 4 perlakuan yang diulang $10 \mathrm{kali}$. Data pengamatan dianalisis secara statistik dengan analisis varians. Perbedaan antara perlakuan diuji dengan uji Jarak Berganda Duncan pada taraf nyata 5\%.

\section{HASIL DAN PEMBAHASAN}

\section{Uji Ketahanan Padi Transgenik terhadap Penggerek Batang Padi Kuning (Scirpophaga incertulas) secara In Planta}

Hasil pengamatan pada 2 minggu setelah infestasi, terlihat intensitas serangan $S$. incertulas pada semua padi yang diuji menunjukkan angka yang tidak berbeda nyata dimana intensitas serangan $S$. incertulas pada semua padi yang diuji terlihat tinggi berkisar antara 73,40\%-96,70\%. Pada pengamatan minggu keempat, intensitas serangan $S$. incertulas pada padi transgenik $D B 1$ terlihat menurun dibandingkan dengan minggu kedua. Namun penurunan intensitas serangan $S$. incertulas pada padi transgenik $D B 1$ dan padi uji lainnya tidak menunjukkan tanaman padi tahan terhadap $S$. incertulas. Dimana dari hasil rata-rata intensitas serangan $S$. incertulas yang dikonversikan dalam 
nilai D menunjukkan bahwa padi transgenik $D B 1$ termasuk dalam kategori tanaman padi yang rentan terhadap $S$. incertulas dengan skala 9. Hasil rata- rata intensitas serangan dapat dilihat pada Tabel 1 dan Tabel 2.

Tabel 1. Rata-rata intensitas serangan $S$. incetulas pada 2 minggu setelah infestasi dan nilai ketahanan tanaman padi pada berbagai perlakuan.

\begin{tabular}{lcccc}
\hline \multicolumn{1}{c}{ Genotipe } & $\begin{array}{c}\text { Rata-rata intensitas serangan minggu } \\
\text { ke-2 } \pm \text { SE (\%) }\end{array}$ & Nilai D (\%) & Skala & \multirow{2}{*}{ Ketahanan } \\
\hline Transgenik $D B 1$ & $96,70 \pm 3,50 \mathrm{a}$ & 117,21 & 9 & $\mathrm{R}$ \\
Taichung-65 & $85,90 \pm 6,03 \mathrm{a}$ & 104,12 & 9 & $\mathrm{R}$ \\
Ciherang & $73,40 \pm 9,74 \mathrm{a}$ & 88,97 & 9 & $\mathrm{R}$ \\
IR64 & $82,50 \pm 6,71 \mathrm{a}$ & 100 & 9 & $\mathrm{R}$ \\
\hline
\end{tabular}

Pada pengamatan minggu keempat (Tabel 2) tampak adanya penurunan intensitas serangan $S$. incertulas pada padi transgenik $D B 1$ dari $96,70 \%$ menjadi 75,90\%. Hal ini diduga disebabkan karena larva $S$. incertulas banyak yang mati pada waktu terjadinya serangan yang tinggi pada minggu ke-2. Dimana pada minggu ke-2 setelah infestasi tanaman padi yang diuji banyak yang layu dan mati sehingga larva $S$. incertulas tidak mampu bertahan hidup karena terjadi persaingan memperoleh makanan. Selain itu, penyebab menurunnya intensitas serangan disebabkan seiringnya pertumbuhan tanaman, anakan baru pada tanaman padi semakin bertambah namun tidak terserang atau tergerek oleh $S$. incertulas. Hal ini juga disebabkan oleh jumlah $S$. incertulas yang hidup dalam tanaman semakin berkurang dan $S$. incertulas yang tersisa sudah mulai memasuki stadia prapupa dan pupa sehingga $S$. incertulas tidak aktif melakukan penggerekkan terhadap tanaman padi. Hal ini dapat dibuktikan dari pengamatan perkembangan $S$. incertulas pada 4 minggu setelah infestasi (Tabel 3).

Tabel 2. Rata-rata intensitas serangan $S$. incetulas pada 4 minggu setelah infestasi dan nilai ketahanan tanaman padi pada berbagai perlakuan.

\begin{tabular}{lcccc}
\hline \multicolumn{1}{c}{ Genotipe } & $\begin{array}{c}\text { Rata-rata intensitas serangan minggu } \\
\text { ke-4 } \pm \text { SE (\%) }\end{array}$ & Nilai D (\%) & Skala & \multirow{2}{*}{ Ketahanan } \\
\hline Transgenik $D B 1$ & $75,90 \pm 6,75$ a & 119,25 & 9 & $\mathrm{R}$ \\
Taichung-65 & $76,90 \pm 6,40$ a & 120,82 & 9 & $\mathrm{R}$ \\
Ciherang & $68,50 \pm 9,51$ a & 107,62 & 9 & $\mathrm{R}$ \\
IR64 & $63,65 \pm 4,60$ a & 100 & 9 & $\mathrm{R}$ \\
\hline
\end{tabular}

Keterangan: Nilai rata-rata yang diikuti dengan huruf yang sama pada kolom yang sama pada masing-masing perlakuan tidak berbeda nyata pada pada DMRT taraf nyata 5\%. SE = Standar Eror, $\mathrm{R}=$ Rentan, $\mathrm{D}=$ persentase sundep terkoreksi galur yang diuji.

Dari hasil pengamatan perkembangan $S$. incertulas terlihat pada padi transgenik $D B 1$ jumlah $S$. incertulas yang masih hidup hanya terdapat 4 ekor yaitu 1 larva dan 3 pupa. Sama halnya dengan padi uji lainnya terlihat jumlah $S$. incertulas yang hidup pada tanaman padi sedikit dan mulai memasuki fase inaktif yaitu stadia prapupa dan pupa. Fenomena ini yang diduga menyebabkan terjadinya penurunan intensitas serangan pada 4 minggu setelah infestasi. Hasil pengamatan ratarata bobot tubuh $S$. incertulas juga menunjukkan perbedaan rata-rata bobot tubuh $S$. incertulas.
Bobot tubuh $S$. incertulas pada padi IR64 lebih berat dibandingkan padi transgenik $D B 1$,Taichung 65 dan Ciherang. Perbedaan bobot tubuh $S$. incertulas kemungkinan diduga karena ketersediaan makanan sehingga berpengaruh terhadap bobot tubuh $S$. incertulas. Dimana pada saat pengujian tanaman padi IR64 mempunyai lebih banyak rumpun (anakan) padi yang tidak terserang (sehat) pada minggu ke-4 dibandingkan padi uji lainnya sehingga $S$. incertulas yang terdapat pada padi IR64 masih mempunyai makanan yang cukup. Hal ini didukung dengan 
pernyataan Hidayat (1990) yang menyebutkan bahwa tersedianya makanan yang cukup bagi larva akan menyebabkan peningkatan berat larva dengan cepat, sebaliknya apabila keadaan makanan kurang maka berat larva akan menurun.

Tabel 3. Rata-rata bobot larva dan pupa $S$. incertulas pada 4 minggu setelah infestasi pada berbagai padi perlakuan.

\begin{tabular}{lcc}
\hline \multicolumn{1}{c}{ Genotipe } & Rata-rata bobot larva $(\mathrm{mg}) \pm$ SE $(\mathrm{n})$ & Rata-rata bobot pupa $(\mathrm{mg}) \pm \mathrm{SE}(\mathrm{n})$ \\
\hline Transgenik $D B 1$ & $2,43 \pm 2,43 \mathrm{a} \mathrm{(1)}$ & $6,38 \pm 3,45 \mathrm{a}(3)$ \\
Taichung-65 & $3,72 \pm 2,48 \mathrm{a} \mathrm{(2)}$ & $0,0 \pm 0,0-(0)$ \\
Ciherang & $1,93 \pm 1,93 \mathrm{a} \mathrm{(2)}$ & $4,59 \pm 3,10 \mathrm{a} \mathrm{(2)}$ \\
IR64 & $18,0 \pm 3,98 \mathrm{~b}(8)$ & $20,2 \pm 4,86 \mathrm{~b}(9)$ \\
\hline
\end{tabular}

Keterangan: Nilai rata-rata yang dii kuti dengan huruf yang sama pada kolom yang sama pada masing-masing perlakuan tidak berbeda nyata pada DMRT taraf nyata $5 \%$. SE = standar eror, $\mathrm{R}=$ rentan, $\mathrm{n}=$ jumlah $S$. incertulas yang hidup.

Dari hasil intensitas serangan $S$. incertulas pada minggu ke-2 dan ke-4 menunjukkan bahwa padi transgenik $D B 1$ tidak dapat meningkatkan ketahanan tanaman terhadap serangan hama $S$. incertulas. Padi transgenik $D B 1$ memiliki tingkat ketahanan yang sama dengan padi Taichung-65, Ciherang dan IR64 yaitu tanaman rentan. Rentannya padi transgenik $D B 1$ diduga karena nutrisi yang dikandung oleh padi transgenik $D B 1$ disukai larva $S$. incertulas untuk tempat makannya sehingga $S$. incertulas aktif menggerek batang padi. Menurut Soejitno (1986) keberadaan nutrisi yang baik akan mengakibatkan larva penggerek batang padi lebih aktif melakukan serangan sehingga larva penggerek batang padi akan menyebabkan serangan yang tinggi pula. Selain itu fisiologi tanaman padi, seperti kandungan air dan pati yang tinggi juga disukai penggerek batang padi (Baco \& Said, 1998).

Rentannya padi transgenik $D B 1$ terhadap $S$. incertulas juga diduga berkaitan dengan morfologi dan anatomi tanaman. Menurut Sodiq (2009) faktor biofisik seperti morfologi, anatomi dan warna tumbuhan mempengaruhi ketahanan suatu varietas. Morfologi dan anatomi tanaman dengan luas daun dan batang yang besar lebih peka terhadap penggerek batang padi (Smith, 1989). Menurut Smith (1989) ketahanan tanaman terhadap serangga menurut morfologi tanaman salah satu diantaranya yaitu trikoma (bulu daun) dan ketebalan jaringan pembuluh. Pada bulu daun, Smith (1989) menggambarkan bahwa trikoma tanaman yang tahan terhadap penggerek batang padi lebih padat dibandingkan dengan tanaman rentan. Carsono et al. (2012) dalam penelitiannya menyatakan bahwa jumlah trikoma pada padi transgenik $D B 1$ sebanyak 27 trikoma $/ \pm 8600 \mu \mathrm{m}^{2}$, Taichung-65 26 trikoma/ $\pm 8600 \mu \mathrm{m}^{2}$, Ciherang 7 trikoma/ $\pm 8600 \mu \mathrm{m}^{2}$, dan IR64 29 trikoma/ \pm 8600 $\mu \mathrm{m}^{2}$. Hal ini menunjukkan kepadatan trikoma yang terdapat pada padi transgenik $D B 1$ dan padi uji lainnya sedikit. Diduga kepadatan trikoma yang sedikit pada padi transgenik $D B 1$ dan padi uji lainnya menyebabkan tanaman menjadi rentan dimana dapat memudahkan larva $S$. incertulas masuk kedalam jaringan tanaman sehingga larva $S$. incertulas lebih mudah menggerek batang padi.

Selain itu, pada pengujian ini tanaman padi transgenik $D B 1$ tidak terbukti mempunyai kemampuan untuk menangkal kerusakan yang disebabkan hama $S$. incertulas. Hal ini diduga efek toksisitas yang diproduksi gen $D B 1$ tidak cukup atau masih rendah. Pada pengujian ini, gen $D B 1$ yang terdapat dalam tanaman kemungkinan terekspresi dengan baik tetapi ekpresi dari gen $D B 1$ tersebut kurang toksik sehingga pada saat pengujian berlangsung ekspresi gen $D B 1$ tersebut tidak mampu mengendalikan $S$. incertulas. Menurut Schuler (2000) tingkat ketahanan tanaman transgenik terhadap hama target tergantung pada tingkat ekspresi dari transgen, sifat toksisitas dari protein yang disandi oleh transgen, dan kerentanan serangga hama target. Pada padi Taichung-65, IR64, dan Ciherang termasuk dalam kategori padi yang rentan karena tanaman tidak memiliki gen ketahanan. Menurut Pathak (1970) sifat ketahanan suatu tanaman ditentukan oleh adanya gen-gen pada tanaman tersebut yang mengendalikan sifat ketahanannya. Kogan (1982) juga menyatakan sumber ketahanan padi nontransgenik umumnya berasal dari karakteristik 
biokimia dan biofisik tanaman yang mempengaruhi perilaku dan metabolisme serangga.

\section{Mortalitas Penggerek Batang Padi Kuning ( $S$. incertulas)}

Pengamatan terhadap tingkat mortalitas dilakukan untuk mengetahui kemampuan padi transgenik $D B 1$ dalam menyebabkan kematian dibandingkan dengan padi yang tidak memiliki gen tahan terhadap $S$. incertulas. Dari hasil pengamatan mortalitas larva $S$. incertulas pada padi transgenik $D B 1$ dan padi uji lainnya (Taichung-65, Ciherang, IR64) tidak menunjukkan perbedaan yang nyata dari semua waktu pengamatan. Pengamatan mortalitas larva $S$. incertulas pada hari pertama sampai hari ketiga terlihat mortalitas larva $S$. incertulas masih terlihat rendah pada padi transgenik $D B 1$ berkisar (25,5\%-50\%). Pada hari keempat sampai hari ketujuh terjadi peningkatan mortalitas larva $S$. incertulas pada padi transgenik $D B 1$ berkisar $(87,5 \%)$. Namun peningkatan mortalitas larva $S$. incertulas pada padi transgenik $D B 1$ terlihat tidak berbeda dengan mortalitas pada padi uji lainnya (Taichung-65, Ciherang dan IR64) selama waktu pengamatan (Tabel 4).

Tabel 4. Rata-rata mortalitas larva $S$. incertulas pada berbagai padi perlakuan.

\begin{tabular}{lccccccc}
\hline \multicolumn{1}{c}{ Perlakuan } & \multicolumn{7}{c}{ Mortalitas $S$. incertulas (\%) pada (n) hari } \\
\hline Transgenik $D B 1$ & $25,5 \mathrm{a}$ & $36,5 \mathrm{a}$ & $50 \mathrm{a}$ & $65 \mathrm{a}$ & $80,5 \mathrm{a}$ & $86 \mathrm{a}$ & $87,5 \mathrm{a}$ \\
Taichung-65 & $31,5 \mathrm{a}$ & $47,5 \mathrm{a}$ & $59,5 \mathrm{a}$ & $67,5 \mathrm{a}$ & $81 \mathrm{a}$ & $87 \mathrm{a}$ & $89 \mathrm{a}$ \\
Ciherang & $24 \mathrm{a}$ & $45 \mathrm{a}$ & $59 \mathrm{a}$ & $68 \mathrm{a}$ & $79 \mathrm{a}$ & $85 \mathrm{a}$ & $89,5 \mathrm{a}$ \\
IR64 & $28 \mathrm{a}$ & $42,4 \mathrm{a}$ & $59,5 \mathrm{a}$ & $70,5 \mathrm{a}$ & $79 \mathrm{a}$ & $86,5 \mathrm{a}$ & $88,5 \mathrm{a}$ \\
\hline Keterangan: Nilai rata-rata yang diikuti dengan huruf yang sama pada kolom yang sama tidak berbeda nyata pada DMRT taraf nyata \\
\end{tabular}

Terjadinya mortalitas pada padi transgenik $D B 1$ mungkin dipengaruhi oleh gen $D B 1$ dimana gen ini diketahui menghasilkan lektin dan mempunyai kemampuan insektisidal sehingga menimbulkan efek toksik terhadap serangga jika terbawa sampai saluran pencernaan (Gaidamashvili et al., 2009). Namun efek toksik yang dihasilkan protein gen $D B 1$ diduga tidak terlalu tinggi sehingga gen $D B 1$ ini tidak mempunyai pengaruh yang besar dalam menyebabkan kematian dimana mortalitas padi transgenik $D B 1$ dengan padi uji tidak menunjukkan adanya perbedaan tingkat mortalitas terhadap larva $S$. incertulas. Berdasarkan hasil pengamatan, padi transgenik $D B 1$ juga diduga tidak efektif mengendalikan larva $S$. incertulas. Hal ini disebabkan karena padi transgenik $D B 1$ tidak tahan (rentan) terhadap $S$. incertulas. Hal ini dibuktikan pada pengujian ketahanan secara in planta pada 2 dan 4 minggu pengamatan diketahui bahwa padi transgenik $D B 1$ dan padi uji lainnya adalah padi yang rentan.

Padi transgenik $D B 1$ dan padi uji lainya menunjukkan adanya peningkatan mortalitas larva $S$. incertulas. Peningkatan mortalitas ini diduga karena pada stadium larva, terjadi persaingan antar individu dalam memperoleh sumber makanan. Menurut (Pathak, 1977), larva penggerek batang padi kuning bersifat kanibalisme. Kondisi ini juga menyebabkan terjadinya mortalitas yang tinggi pada larva $S$. incertulas. Pada pengujian tanaman transgenik $D B 1$ ini, terlihat adanya perbedaan hasil pengujian yang dilakukan oleh Gaidamashvili pada tahun 2009 dimana gen ini gen $D B 1$ terbukti dapat menghambat perkembangan Helicoverpa armigera. Hal ini kemungkinan disebabkan karena perbedaan spesies serangga yang diuji. Menurut Sudhakar et al. (1998), lektin yang bersifat toksik mempunyai tingkat toksisitas yang berbeda terhadap spesies serangga yang berbeda.

Pengaruh Padi Transgenik terhadap Lama Perkembangan Penggerek Batang Padi Kuning $(S$. incertulas)

Tanaman padi transgenik selain mempunyai kemampuan untuk menangkal kerusakan juga mempunyai kemampuan untuk menghambat pertumbuhan hama $S$. incertulas. Pada pengujian ini terlihat pada padi transgenik $D B 1$ lama perkembangan $S$. incertulas dari larva instar 1 sampai instar 4 cenderung tidak berbeda dibandingkan dengan padi uji lainnya kecuali pada perkembangan instar 1 sampai instar 2 padi transgenik $D B 1$ lebih cepat (6,2 hari). Namun perbedaan lama perkembangan mulai terlihat dari 
instar 1 sampai instar 5 dan instar 1 sampai prapupa dimana perkembangannya $S$. incertulas pada padi transgenik lebih lama dibandingkan dengan padi uji lainnya. Pada padi transgenik $D B 1$ lama perkembangan dari instar 1 sampai instar 5 selama
23,1 hari dan instar 1 sampai prapupa selama 26,9 hari sedang pada padi uji lainnya lama perkembangan dari instar 1 sampai instar 5 berkisar antara 21,2-21,7 hari dan instar 1 sampai prapupa berkisar antara 23,7-24,5 hari (Tabel 5).

Tabel 5. Rata-rata lama perkembangan $S$. incertulas.

\begin{tabular}{|c|c|c|c|c|c|}
\hline \multirow{2}{*}{ Genotip } & \multicolumn{5}{|c|}{ Lama perkembangan $S$. incertulas (hari) $\pm \mathrm{SB}$ (n) } \\
\hline & Instar 1-2 & Instar 1-3 & Instar 1-4 & Instar 1-5 & Instar 1-prapupa \\
\hline Transgenik $D B 1$ & $6,2 \pm 1,7(38)$ & $12,8 \pm 2,0(18)$ & $18,8 \pm 2,8(15)$ & $23,1 \pm 3,5(14)$ & $26,9 \pm 2,9(8)$ \\
\hline Taichung-65 & $8,3 \pm 1,4(33)$ & $13,2 \pm 1,8(19)$ & $17,5 \pm 2,2(13)$ & $21,2 \pm 2,3(13)$ & $23,7 \pm 1,7(12)$ \\
\hline Ciherang & $8,2 \pm 1,6(20)$ & $14,4 \pm 2,6(14)$ & $18 \pm 2,3(11)$ & $21,7 \pm 3,3(9)$ & $24,3 \pm 3,4(8)$ \\
\hline IR64 & $6,7 \pm 1,9(53)$ & $12,4 \pm 2,5(27)$ & $17,5 \pm 3,1(21)$ & $21,3 \pm 3,7(18)$ & $24,5 \pm 4,3(14)$ \\
\hline
\end{tabular}

Keterangan: $\mathrm{SB}=$ simpangan baku, $\mathrm{n}=$ jumlah $S$. incertulas.

Dalam pengujian ini, hasil yang didapat dari lama perkembangan $S$. incertulas dari instar 1 sampai instar 4 tidak menujukkan adanya perbedaan lama perkembangan $S$. incertulas dengan padi transgenik $D B 1$. Hal ini mungkin disebabkan karena padi yang diuji sama rentannya terhadap $S$. incertulas dimana sumber ketahanan yang dimiliki padi transgenik yaitu gen $D B 1$ diduga kurang toksik sehingga tidak mampu menghambat perkembangan larva $S$. incertulas dari instar 1 sampai instar 4 . Sementara itu, pada padi transgenik $D B 1$ terlihat lama perkembangan dari instar 1 sampai instar 5 dan instar 1 sampai prapupa mengalami perkembangan yang lebih lama bila dibandingkan dengan padi uji lainnya. Namun lama perkembangan dari instar 1 sampai 5 (23,1 hari) dan instar 1 sampai prapupa
(26,9 hari) tersebut masih sesuai dengan waktu perkembangan $S$. incertulas secara normal. Hasil tersebut sesuai dengan pernyataan Kalshoven (1981) perkembangan larva $S$. incertulas berkisar 3-6 minggu. Selain itu, faktor lingkungan diduga menjadi salah satu faktor yang memengaruhi lama perkembangan $S$. incertulas. Menurut Hendarsih \& Usyati (2005), perkembangan $S$. incertulas juga dipengaruhi oleh keadaan suhu, temperatur dan makanan.

Pengamatan terhadap pertumbuhan $S$. incertulas juga dilakukan seiring perubahan instar $S$. incertulas pada semua padi yang diuji dengan cara mengukur panjang tubuh. Hasil pengamatan ratarata panjang tubuh $S$. incertulas dapat dilihat pada Tabel 6.

Tabel 6. Rata-rata panjang tubuh $S$. incertulas.

\begin{tabular}{lcccccc}
\hline \multirow{2}{*}{ Perlakuan } & \multicolumn{5}{c}{ Panjang tubuh $S$. incertulas $(\mathrm{mm}) \pm \mathrm{SB}(\mathrm{n})$} \\
\cline { 2 - 7 } & Instar 1 & Instar 2 & Instar 3 & Instar 4 & Instar 5 & Prapupa \\
\hline Transgenik & $1,4 \pm 0,08$ & $4,3 \pm 0,64$ & $8,7 \pm 1,86$ & $14,5 \pm 1,44$ & $19,0 \pm 1,33$ & $15,0 \pm 0,88$ \\
$D B 1$ & $(20)$ & $(38)$ & $(17)$ & $(14)$ & $(14)$ & $(14)$ \\
Taichung-65 & $1,4 \pm 0,08$ & $4,8 \pm 1,00$ & $10,6 \pm 1,68$ & $15,1 \pm 1,40$ & $19,4 \pm 1,64$ & $15,0 \pm 1,18$ \\
& $(20)$ & $(33)$ & $(19)$ & $(13)$ & $(13)$ & $(12)$ \\
Ciherang & $1,4 \pm 0,08$ & $4,9 \pm 1,06$ & $9,5 \pm 1,52$ & $14,5 \pm 1,68$ & $19,3 \pm 2,17$ & $15,7 \pm 2,31$ \\
& $(20)$ & $(20)$ & $(12)$ & $(10)$ & $(8)$ & $(7)$ \\
IR64 & $1,4 \pm 0,08$ & $4,4 \pm 0,80$ & $9,7 \pm 2,17$ & $15,2 \pm 1,84$ & $20,8 \pm 2,79$ & $15,7 \pm 1,67$ \\
& $(20)$ & $(53)$ & $(26)$ & $(21)$ & $(16)$ & $(13)$ \\
\hline
\end{tabular}

Keterangan: $\mathrm{SB}=$ simpangan baku, $\mathrm{n}=$ jumlah $S$. incertulas.

Hasil pengukuran panjang tubuh $S$. incertulas selama waktu percobaan berlangsung menunjukkan rata- rata panjang tubuh $S$. incertulas pada semua padi yang diuji cenderung tidak berbeda kecuali pada padi transgenik $D B 1$ terlihat larva $S$. incertulas instar 3 lebih pendek yaitu $8,7 \mathrm{~mm}$ sedangkan padi uji lainnya berkisar 9,50-10,6 mm. Namun demikian, adanya perbedaan ukuran tubuh $S$. incertulas ini tidak menunjukkan bahwa larva $S$. incertulas mengalami gangguan pertumbuhan 
karena pada instar berikutnya larva $S$. incertulas masih mampu bertahan hidup sampai stadium prapupa. Lama perkembangan dan pertumbuhan serangga merupakan salah satu hal yang harus dipertimbangkan dalam menentukan suatu tanaman tahan atau tidak tahan. Menurut Manwan (1975) varietas padi yang tahan terhadap penggerek batang padi pada umumnya larva yang hidup pada varietas tersebut hidupnya terganggu, pertumbuhan terlambat, ukuran badannya lebih kecil, kematiannya tinggi, persentase menjadi pupa rendah. Hal ini menunjukan bahwa pada padi transgenik $D B 1$ dan padi nontransgenik (Taichung65, Ciherang, IR64) bukan padi yang tahan terhadap $S$. incertulas karena larva yang hidup pada tanaman tersebut, hidupnya tidak terganggu, pertumbuhan larvanya tidak terlambat dan mampu bertahan hidup sampai stadium prapupa.

Perkembangan $S$. incertulas yang tidak mengalami gangguan ditunjukkan semakin bertambahnya panjang ukuran tubuh $S$. incertulas seiring dengan perubahan instar. Hal ini diduga disebabkan karena tersedianya kualitas sumber makanan yang baik bagi $S$. incertulas diikuti dengan kerentanan (tidak tahan) pada padi yang diuji. Menurut Ellers-Kirk \& Fleischer (2006) dalam Win et al. (2011) bahwa perkembangan serangga, lamanya hidup dan kapasitas reproduksi dipengaruhi oleh kualitas sumber makanan yang tersedia bagi serangga. Hal ini menunjukkan bahwa padi transgenik $D B 1$ dan padi uji lainnya merupakan sumber pakan yang berkualitas bagi $S$. incertulas. Dengan kondisi demikian, maka padi yang rentan terhadap $S$ incertulas tidak akan mampu menghambat perkembangan dan pertumbuhan $S$. incertulas.

\section{SIMPULAN}

Hasil penelitian menunjukkan bahwa ketahanan padi transgenik $D B 1$, Taichung-65, IR64 dan Ciherang terhadap penggerek batang padi kuning (Scirpophaga incertulas) merupakan padi yang rentan dengan skala 9. Mortalitas pada padi transgenik $D B 1$ juga tidak berbeda dengan padi Taichung-65, IR64 dan Ciherang. Rendahnya tingkat ketahanan pada empat jenis padi ini juga terlihat pada lama perkembangan dan pertumbuhan $S$. incertulas yang relatif sama dimana tidak nampak ada gangguan perkembangan dan pertumbuhan $S$. incertulas.

\section{UCAPAN TERIMAKASIH}

Ucapan terima kasih disampaikan kepada beberapa peneliti di BB Penelitian Tanaman Padi, Sukamandi, Subang.

\section{DAFTAR PUSTAKA}

Baco, D, dan MY Said. 1998. Perubahan populasi penggerek putih dan faktor penyebabnya pada padi di Sulawesi Selatan. Penelitian Pertanian Tanaman Pangan. 17(1): 13-19.

Bahagiawati, dan H Rijzaani. 2005. Pengelompokan biotipe wereng coklat berdasarkan hasil PCR-RAPD. Hayati. 12(1):1-6.

Bandong, JP, and JA Litsinger. 2005. Rice crop stage susceptibility to the rice yellow stemborer, Scirpophaga incertulas (Walker) (Lepidoptera) (Pyralidae). Inter. Jour. Pest Manag. 51(1):37-43.

Carsono, N, GI Prayoga, NK Willis, D Dono, A Wahyudin, D Damayanti, M Herman, and K Toriyama. 2012. Population build-up of brown planthoppers on DB1 transgenic and non-transgenic rice cultivars. Proceeding The International Conference on Sustainable Agriculture and Food Security (ICSAFS). Pp. 267-272.

Gaidamashvili, M, Y Ohizumi, T Ogawa, and K Muramoto. 2009. Binding of the insecticidal DB1 lectin in Helicoverpa armigera (Hübner) midgut epithelia. Bulletin of The Georgian National Academy of Sciences. 3(2):147-149.

Gaidamashvili, M, Y Ohizumi, S Iijima, T Takayama, T Ogawa, and K Muramoto. 2004. Characterization of yam tuber storage proteins from Dioscorea batatas exhibiting unique lectin activities. J Biol Chem 279: 26028-26035.

Hendarsih, S, and N Usyati. 2005. The stemborer infestation on rice cultivar at three planting times. Indonesian Journal of Agricultural Science. 6(2): 39-45.

Hidayat, N. 1990. Entomologi Pertanian. Orba Sakti, Bandung.

Kalshoven, LGE. 1981. The Pest of Crops in Indonesia. Revised and translated by PA Van der Laan. PT. Ichtiar Baru-Van Hoeve, Jakarta.

Kogan, M. 1982. Plant resistance in pest management. Pp. 93-134 in Introduction to 
Insect Pest Management (RL Metcalf and WH Luckmann, Eds.). Second Edition. John Wiley \& Sons, New York.

Manwan, I. 1975. Resistance of rice varieties to yellow stem borer, Tryporyza incertulas (Walker). [Thesis]. UPLB, Los Banos Philippines.

Ohizumi, Y, M Gaidamashvili, S Ohwada, K Matsuda, J Kominami, S Nakamura-Tsuruta, J Harabayasi, T Naganuma, T Ogawa, and K Muramoto. 2009. Mannose-binding lectin from yam (Dioscorea batatas) tubers with insecticidal properties against Helicoverpha armigera (Lepidoptera: Noctuidae). J. Agric. Food. Chem. 57:2896-2902.

Pathak, MD. 1970. Feasibility of utilizing arietal resistance in insect control. Paper Presented at Conferance on Pest Management. North Caroline State Univ. 25-27 March 1970. 30 p.

Pathak, MD. 1977. Insect Pest of Rice. The International Rice Research Institute. Los Banos, Philipines. Pp. 2-12.

Rao, PSP, and G Padhi. 1988. Improved sources of plant resistance to yellow stem borer (YSB) Scirpophaga incertulas Walker in rice. Intl. Rice Res. Newsl. 13(5):15.

Schuler, TH. 2000. The impact of insect resistant GM crops on populations of natural enemies. Antenna. 24:59-65.

Smith, CM. 1989. Plant Resistance to Insects. John Wiley \& Sons, New York. 286 pp.
Sodiq, M. 2009. Ketahanan Tanaman Terhadap Hama. UPN Press, Jawa Timur. 78 hlm.

Soejitno, J. 1986. Pengaruh serangan penggerek batang padi kuning (Tryporyza incertulas Walker) (Lepidoptera: Pyralidae) pada berbagai umur tanaman terhadap kerusakan tanaman padi. Penelitian Pertanian. 6(1): 43-48.

Soehardjan, MM. 1976. Dinamika populasi penggerek batang padi kuning Tryporiza incertulas Walker (Lepidoptera : Pyralidae). Kongres Entomologi I. Jakarta. Hlm. 15-26.

Sudhakar, D, X Fu, E Stoger, S Williams, J Spence, PD Brown, M Bharathi, A Gatehouse, and P Christou. 1998. Expression and immunolocalization of the snowdrop lectin, GNA in transgenic rice plants. Transgenic Research. 7:1-18.

Toriyama, K. 2010. Production of transgenic plants expressing Dioscorea batatas tuber lectin 1 to confer resistance against sup-sucking pests. Tohoku University, Sendai, Japan. International Seminar Biotechnology. Available at: http://pustaka.unpad.ac.id/wpcontent/uploads/2011/01/ production_of_transgenic_plants_expressin g.pdf (accessed on 21 February 2011).

Win, SS, R Muhamad, Z Abidin, M Ahmad, and NA Adam. 2011. Life table and population parameters of Nilaparvata lugens Stal. (Homoptera: Delphacidae) on rice. Tropical Life Sciences Research. 22 (1): 25-35. 